\title{
A new perspective in e-learning training toolkit development for advanced textile research centres in Morocco and Jordan
}

DOI: $10.35530 / 1 T .072 .05 .1849$

RALUCA MARIA AILENI

RAZVAN ION RADULESCU

LAURA CHIRIAC

\author{
ABSTRACT - REZUMAT \\ A new perspective in e-learning training toolkit development for advanced textile research centres \\ in Morocco and Jordan
}

\begin{abstract}
This paper presents an overview of training/learning tools for advanced textile research centres in Morocco and Jordan. Within the Erasmus+ FOSTEX project, the main courses necessary for the training of researchers and students enrolled in master's or doctoral programs in Morocco and Jordan and who will work within the advanced research centres have been identified and selected. Starting from good European practices on learning, teaching, research and testing services, several courses have been structured that offer knowledge on international conformity certification, standardization, quality management, testing/inspection, labelling, integration of technical specifications, testing physical-mechanical, colour resistance testing, tests specific to instrumental analysis and development of advanced materials. In order to improve the skills of human resources (research staff, masters and doctoral students), the Erasmus+ FOSTEX consortium has developed an extensive toolkit of learning-training, thematic workshops and services appropriate to the equipment purchased by partners in Morocco and Jordan for research centres in the field of advanced textiles.
\end{abstract}

Keywords: research, advanced materials development, testing, standardization, e-learning, training

O nouă perspectivă în dezvoltarea setului de intrumente de formare e-learning pentru centrele de cercetare în domeniul textilelor avansate din Maroc și lordania

Această lucrare prezintă o vedere de ansamblu a instrumentelor de formare/învățare pentru centrele cercetare în domeniul textilelor avansate realizate în Maroc și lordania. În cadrul proiectului Erasmus+ FOSTEX au fost identificate și selectate principalele cursuri necesare pentru formarea cercetătorilor şi studenților înscriși în programe de masterat sau doctorat din Maroc și lordania şi care vor lucra în cadrul centrelor de cercetare avansată. Pornind de la bunele practici europene privind învățarea, predarea, activitatea de cercetare și serviciile de testare, au fost structurate mai multe cursuri care oferă cunoștințe despre certificarea de conformitate internaţională, standardizare, managementul calității, testare/inspecție, etichetare, integrarea specificațiilor tehnice, testare fizico-mecanică, testarea rezistentei culorii, teste specifice analizei instrumentale și dezvoltarea materialelor avansate. Pentru a îmbunătăți abilitățile resurselor umane (personal de cercetare, masteranzi și doctoranzi), consorțiul Erasmus+ FOSTEX a dezvoltat un set de instrumente de învățare-formare extins, ateliere tematice și servicii adecvate echipamentelelor achiziționate de partenerii din Maroc și lordania pentru centrele de cercetare în domeniul textilelor avansate.

Cuvinte-cheie: cercetare, dezvoltarea materialelor avansate, testare, standardizare, e-learning, formare

\section{INTRODUCTION}

In the Erasmus+ FOSTEX project, tremendous work was to develop the courses modules in the framework of the learning toolkit, taking into account the particularities of the advanced centres established in Jordan and Morocco such as the equipment purchased in the framework of the Erasmus+ FOSTEX project, services proposed, and background of the human resources involved in the advanced textile centres created or updated. Starting from the best practices database containing the examples of learning, teaching (courses), dissemination, quality testing, standardization, equipment acquisitions, educational, and research projects, were developed and provided a set of courses (toolkit) about international conformity certification, standardization, quality management, inspection vs. testing of the textiles (protective textile testing, washing fastness, colour fastness testing, tensile strength testing), instrumental analysis, colour management and communication, integration of textile testing result into technical specifications, environmental legislation and advanced composites development based on plasma, 3D printing, polymeric matrix, fibres, nonwoven, knitted structures and micro/nanoparticles for functionalization. In addition, based on the final list of equipment purchased by partners from Jordan and Morocco was provided an adequate selection of services and thematic workshops usefully to be developed. In order to deliver attractive courses in the context of the Covid-19 crisis, have been used formal or informal teaching/ 
learning methods in the virtual classroom established using dedicated software for meeting applications.

The proposed courses, services and workshops aim to improve the knowledge, to foster the collaboration in research [1, 2] or educational projects between EU and Moroccan and Jordanian universities in the advanced textiles sector and to co-create innovation and training network that will continue to produce sustainable results after the end of the project.

The knowledge about advanced textile materials must be permanently updated with advanced knowledge from other disciplines (physics, chemistry, mechanics, biology, and electronics). To increase the students' attention and perception and to attract them to learn about new materials was very important to prepare an adequate interactive presentation mixing the slides, images, exercises, sound and videos. In addition, the knowledge level can be improved by seminars, workshops, e-learning and training, as well as real practice in laboratories. However, for upgrading or development of new research centres (Jordan, Morocco) are very important the infrastructure and human resources qualifications, as well as the continuous learning.

This paper contains an overview of the international conformity certification, labelling and technical specifications, quality management, environmental legislation and inspection/testing (physico-mechanical testing, colour fastness testing and the testing suite provided by a large group of instrumental analyses).

\section{INTERNATIONAL CONFORMITY CERTIFICATION}

Conformity represents compliance with standards, rules, or laws. Conformity assessment involves a set of processes that show your product, service or system meets a standard's requirements. CASCO
Committee (ISO's Committee on Conformity Assessment) develops standards and addresses issues related to conformity assessment (figure 1). The main forms of conformity assessment are testing, certification and inspection.

Textile testing is the determination of one or more of the textile product's characteristics and is usually performed by a laboratory. CASCO has developed several standards that laboratories can follow to help ensure that their results can be trusted. Inspection describes the regular checking of a product to make sure it meets specified criteria. Firefighters' PPE, for example, need regular inspections to ensure they are safe for use (ISO/CD 23616).

Certification is a useful tool to add credibility by demonstrating that your product or service meets your customers' expectations. For some industries, certification is a legal or contractual requirement. However, ISO does not perform certification and does not issue certificates. CASCO has produced some standards related to the certification process, which are used by certification bodies. Certification is certifying that the product, service or system in question meets specific requirements. Certification is also known as third-party conformity assessment [3, 4]. For example, companies and organizations are certified to management system standards (ISO 9001). In this way, get visible that the organization has a quality management system implemented. CE marking (European conformity certification) signifies that the EEA (European Economic Area) products have been assessed to meet high safety, health, and environmental protection requirements. CE marking is a part of the EU's harmonization legislation. CE marking on the textile product is a declaration that the product meets all the legal requirements for CE marking and can be sold throughout the EEA. This also applies to products made in other countries that are sold in the EEA.

Benefits of the CE marking:

- Businesses know that products bearing the CE marking can be traded in the EEA without restrictions;

- Consumers enjoy the same level of health, safety, and environmental protection throughout the entire EEA.

Certificate of Conformity ( $\mathrm{CoC}$ ), also named Certificate of Compliance, is a mandatory document necessary for Customs clearance of exports to many countries around the globe.

$\mathrm{CoC}$ is a document certified by a competent authority that the supplied good or service meets the required specifications.

CoC shows that the goods being exported comply with the relevant technical regulations and national,

Fig. 1. Structure of CASCO (Source: www.iso.org) 
regional or international standards of import, protecting citizens' health, safety, and the environment from substandard imported goods and giving them the assurance they need in their local market.

Certification $\neq$ Approval (Organizations such as Underwriters Laboratories, TÜV Rheinland, NTA Inc, and CSA International test the products according to standard procedures and declare that the product is compliant with the standard).

The technical documentation contain the information on the design, manufacture and all the details necessary to demonstrate the product conforms to the applicable requirements [5].

In case of the manufacturer, the certification is required as evidence or proofs that products or services meet regulations, standards or other requirements before placing the product on the market.

\section{QUALITY MANAGEMENT AND ADVANCED MATERIALS TESTING}

\section{Quality management/Quality assurance}

Quality management [6, 7] is providing confidence that quality requirements are achieved. Quality control is a "part of quality management focused on fulfilling quality requirements".

Quality assurance (QA) [8, 9] is used to prevent defects in products manufactured when delivered to customers and can be achieved through inspection. Inspection is the process of measuring, examining, and testing the product /service characteristics and comparing the testing results with specified requirements to determine conformity [10].

\section{Testing}

Testing [11] is a part of quality assurance -inspection, being an activity developed to measure the quality of the product characteristics.

To prepare a high-quality set of requirements specifications for products it is mandatory to verify the product's technical characteristics by testing the product in accredited laboratories.

We need to test the mechanical, chemical or electrical properties of the product to evaluate the quality of the product's characteristics and to answer if the product has the performance (numerical values of the parameters tested) in line with the technical requirements and specifications.

These numerical values of the parameters (mechanical or chemical, electrical) obtained by testing are useful in production, purchasing and claims.

The testing activity can be performed during product development to assure that the quality meets expectations. The results of the tests are useful in identifying the appropriate parameters that should be improved/optimised in production. The testing results following the European and international standards (ISO) can be used to certify that your product meets the expected requirements. In addition, the test results can also help resolve complaints seeking damages.

Physico-mechanical testing

Tensile strength testing can be performed through 2 methods grab and strip using standards ISO 13934 and ISO 13935.

The standard ISO 13934 is used for the determination of mechanical properties of textiles using mainly tensile testing machines, e.g. tensile properties, seam tensile properties, tear properties, seam slippage.

Tensile properties (maximum force or elongation at maximum force) of the textiles (woven structures) can be investigated by 2 methods:

- Strip method (ISO 13934-1:2013) allows determination of maximum force and elongation [12];

- Grab method (ISO 13934-2:2014) allows the determination of maximum force [13].

ISO 13935 is used for the determination of seam maximum force of sewn seams when the force is applied perpendicularly to the seam. Tensile properties (seam maximum force of sewn seams when the force is applied perpendicularly to the seam) can be investigated using 2 methods:

- Strip method (ISO 13935-1:2014) allows determination of maximum force to seam rupture [14];

- Grab method (ISO 13935-2:2014) allows determination of maximum force to seam rupture [15].

Colour fastness testing

Colour fastness represents the resistance of the colour of textiles to the different agents (figure 2) to which these materials may be exposed during manufacture and wearing.

The most used colour fastness tests in textile industry are:

- Colour fastness to perspiration (ISO 105-E04: 2013) [16];

- Colour fastness to wash (ISO 105-C10:2006, ISO 105-C06:2010) [17, 18];

- Colour fastness to light: daylight (ISO 105-B01: 2014) [19];

- Colour fastness to artificial light (ISO 105-B02: 2014) [20];

- Colour fastness to water (ISO 105-E01:2013) [21];

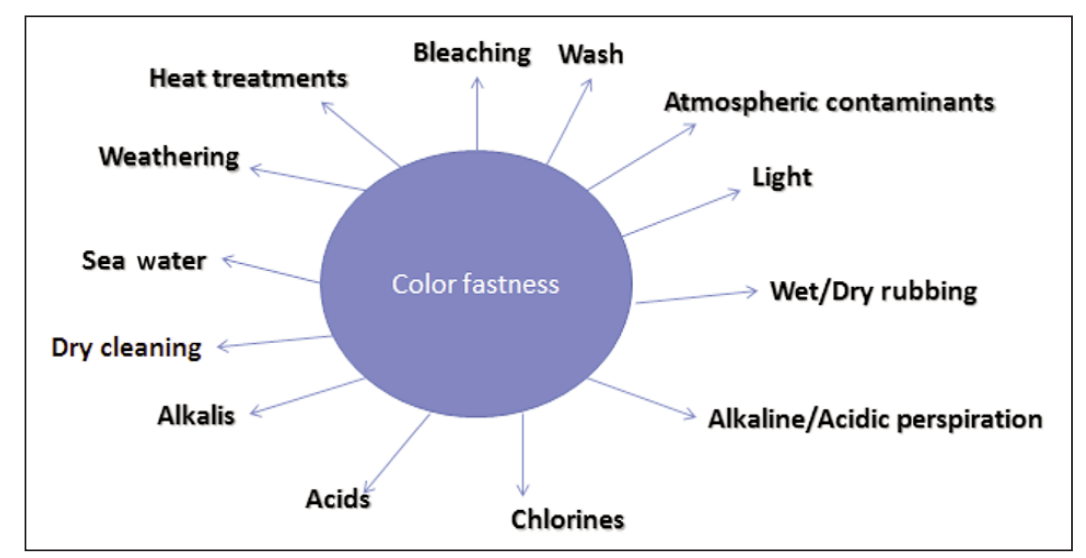

Fig. 2. Types of colour fastness testing 
- Colour fastness to rubbing (ISO 105-D02:2016, ISO 105-X16:2016, ISO 105-X12:2016) [22-24];

- Colour fastness to hot pressing (ISO 105-X11: 1994) [25].

Instrumental analysis

Analytical instrumentation is crucial to molecular biology, medicine, geology, food science, or materials science [26-29]. For each classical or instrumental analysis method are defined the adequate qualitative and quantitative methods [30-32].

- A qualitative method provides information about the identity of atomic/molecular species and functional groups of the sample.

- A quantitative method provides numerical information about the relative amount of one or more components.

Then qualitative and quantitative analysis can be performed, often with the same instrument and may use light interaction, heat interaction, electric fields or magnetic fields [33-35]. Instrumental analysis methods may be elemental or molecular analysis using qualitative and quantitative methods (tables 1 and 2) [36-38].

Some of the presented methods can be used in the investigation of the textile materials, additional micro/nanoparticles present on the textile surface [35]. Below are presented the main applications of instrumental methods [31, 33-35] (elemental and molecular analysis):

\section{Elemental analysis}

- Atomic absorption spectrometry (AAS)

Qualitative analysis of the AAS method is not used routinely for qualitative analysis, since with most instruments; it is only possible to test for one element at a time.

Quantitative analysis of the AAS method is a very accurate and sensitive method for the quantitative investigation of metals and metalloids down to absolute amounts as low as picograms for some elements. It cannot be used directly for the determination of non-metals.

\section{- X-ray fluorescence (XRF)}

The XRF method's qualitative analysis is useful for elements with atomic numbers greater than 4 , including metals and non-metals. For qualitative analysis, no sample preparation is required, and the method is generally non-destructive.

Quantitative analysis of the XRF method is used extensively for the quantitative determination of elements in alloys and mineral samples, particularly of elements with high atomic weights. Sample preparation is elaborate for quantitative analysis.

\section{- Atomic emission spectrometry (AES), Optical emission spectrometry (OES)}

Qualitative analysis in the case of the AES method is an almost comprehensive method for qualitative elemental analysis for metals, metalloids, and non-metals except for some permanent gases. Its sensitivity range is good, varying from ppb to percent levels. It has the advantage that many elements can be

\begin{tabular}{|c|c|c|c|c|}
\hline \multicolumn{5}{|c|}{ INSTRUMENTAL METHODS OF ANALYSIS [32] } \\
\hline \multirow{2}{*}{ Method } & \multicolumn{2}{|c|}{ Qualitative } & \multicolumn{2}{|c|}{ Quantitative } \\
\hline & Elemental & Molecular & Elemental & Molecular \\
\hline Atomic absorption spectrometry & No & No & Yes & No \\
\hline Atomic emission spectrometry & Yes & No & Yes & No \\
\hline Capillary electrophoresis & Yes & Yes & Yes & Yes \\
\hline Electrochemistry & Yes & Yes & Yes & Yes \\
\hline Gas chromatography & No & Yes & No & Yes \\
\hline ICP-mass spectroscopy & Yes & No & Yes & No \\
\hline Infrared spectroscopy & No & Yes & No & Yes \\
\hline Ion chromatography & Yes & Yes & Yes & Yes \\
\hline Liquid chromatography & No & Yes & No & Yes \\
\hline Mass spectroscopy & Yes & Yes & Yes & Yes \\
\hline Nuclear magnetic resonance & No & Yes & No & Yes \\
\hline Raman spectroscopy & No & Yes & No & Yes \\
\hline Thermal analysis & No & Yes & No & Yes \\
\hline UVIVIS spectrophotometry & Yes & Yes & Yes & Yes \\
\hline UV absorption & No & Yes & No & Yes \\
\hline UV fluorescence & No & Yes & No & Yes \\
\hline X-ray absorption & Yes & No & Yes & No \\
\hline X-ray diffraction & No & Yes & No & Yes \\
\hline X-ray fluorescence & Yes & No & Yes & No \\
\hline
\end{tabular}




\begin{tabular}{|c|c|c|c|c|c|}
\hline \multicolumn{6}{|c|}{ ANALYTICAL CONCENTRATION RANGES FOR COMMON INSTRUMENTAL METHODS [32] } \\
\hline Technique & Destructive & $\begin{array}{l}\text { Ultratrace } \\
(<1 \mathrm{ppm})\end{array}$ & $\begin{array}{c}\text { Trace } \\
\text { (1 ppm-0.1\%) }\end{array}$ & \begin{tabular}{|c|} 
Minor \\
$(0.1 \%-10 \%)$
\end{tabular} & $\begin{array}{c}\text { Major } \\
(>10 \%)\end{array}$ \\
\hline X-ray diffraction & No & No & No & Yes & Yes \\
\hline Nuclear magnetic resonance & No & No & Yes & Yes & Yes \\
\hline X-ray fluorescence & No & No & Yes & Yes & Yes \\
\hline Infrared spectroscopy & No & No & Yes & Yes & Yes \\
\hline Raman spectroscopy & No & No & Yes & Yes & Yes \\
\hline UV/VIS spectrometry & No & No & Yes & Yes & Yes \\
\hline Colorimetry & No & Yes & Yes & Yes & No \\
\hline Molecular fluorescence spectrometry & No & Yes & Yes & Yes & Yes \\
\hline Atomic absorption spectrometry & Yes & Yes & Yes & Yes & No \\
\hline Atomic emission spectrometry & Yes & Yes & Yes & Yes & Yes \\
\hline Atomic fluorescence spectrometry & Yes & Yes & Yes & No & No \\
\hline ICP-mass spectrometry & Yes & Yes & Yes & Yes & No \\
\hline Organic mass spectrometry & Yes & Yes & Yes & Yes & Yes \\
\hline GC-MS & Yes & Yes & Yes & Yes & Yes \\
\hline LC-MS & Yes & Yes & Yes & Yes & Yes \\
\hline Potentiometry & No & Yes & Yes & Yes & Yes \\
\hline Voltammetry & No & Yes & Yes & Yes & Yes \\
\hline Gas chromatography & May be & Yes & Yes & Yes & Yes \\
\hline High-performance liquid chromatography & May be & Yes & Yes & Yes & Yes \\
\hline Ion chromatography & May be & Yes & Yes & Yes & Yes \\
\hline Capillary electrophoresis & No & Yes & Yes & Yes & Yes \\
\hline Thermal analysis & Yes & No & No & Yes & Yes \\
\hline
\end{tabular}

detected simultaneously. However, the spectral overlap is the major limitation.

Quantitative analysis in the case of the AES method is used extensively to determine elements in concentrations from percent levels down to ppb. Liquids, slurries, and solids can be analysed using the appropriate instrumentation.

Molecular analysis

\section{- Nuclear magnetic resonance (NMR) spec- troscopy}

Qualitative analysis in the case of the NMR method is used to investigate the structure of molecules. NMR identifies the number and type of protons and carbon atoms in organic molecules (e.g., among aromatic, aliphatic, alcohols, and aldehydes)

Quantitative analysis of the NMR method is useful at percentage concentration levels, but trace levels (ppm) are becoming attainable with reasonable accuracy.

\section{- Infrared (IR) spectroscopy}

Qualitative analysis in the IR method identifies organic functional groups present in molecules, including groups containing heteroatoms: $\mathrm{O}, \mathrm{S}, \mathrm{N}, \mathrm{Si}$, halides. The conventional spectrometers systems have been replaced by Fourier transform IR (FTIR) instrumentation.

Quantitative analysis of the IR method is used routinely for the quantitative analysis of organic com- pounds, particularly at percentage concentration levels.

\section{- Fourier-transform infrared spectroscopy (FTIR)}

FTIR is a spectroscopic technique used to obtain an infrared spectrum of absorption or emission of a solid, liquid or gas. FTIR spectrometer collects highspectral-resolution data over a wide spectral range. The theory is based on the fact that different elements absorb light at different frequencies. FTIR is used because it can produce an interferogram within a second. FTIR analysis method uses infrared light to scan test samples and observe the organic, polymeric, or inorganic materials' chemical properties.

\section{- UV and visible (UV/VIS) spectrophotometry}

Qualitative analysis UV/VIS of the organic or inorganic reagents is used for specific tests for many elements or compounds by forming a compound that absorbs specific wavelengths. The products may or may not be coloured. For compounds that are coloured, the analysis may be carried out visually (colorimetric analysis by eye), but a spectrometer is more accurate. The interaction of UV and visible radiation with matter can provide qualitative identification of molecules and polyatomic species, including ions and complexes. Qualitative information is usually obtained by observing the UV/VIS spectrum, the absorption of UV and visible radiation as a function of 


\begin{tabular}{|l|l|l|}
\hline \multicolumn{3}{|c|}{ SPECTROMETRY USING UV AND VISIBLE LIGHT [32] } \\
\hline \multicolumn{3}{|c|}{ Spectrometry using UV and Visible Light } \\
\hline \multicolumn{2}{|c|}{ Function } & \multicolumn{1}{|c|}{ Atomic spectroscopy } \\
\hline \multicolumn{3}{|c|}{ Analytical application } \\
\hline $\begin{array}{l}\text { Absorption of UV/VIS } \\
\text { radiation }\end{array}$ & $\begin{array}{l}\text { Atomic absorption spectrometry } \\
\text { (AAS) }\end{array}$ & Quantitative elemental analysis \\
\hline $\begin{array}{l}\text { Emission of UV/VIS } \\
\text { radiation }\end{array}$ & $\begin{array}{l}\text { Flame photometry, Auger electron } \\
\text { spectroscopy (AES) }\end{array}$ & Qualitative and quantitative multi-element analysis \\
\hline $\begin{array}{l}\text { Emission of UV/VIS } \\
\text { radiation }\end{array}$ & $\begin{array}{l}\text { Atomic fluorescence spectroscopy } \\
\text { (AFS) }\end{array}$ & $\begin{array}{l}\text { Quantitative elemental analysis of ultra-trace concentra- } \\
\text { tions (sub-ppb) }\end{array}$ \\
\hline \multicolumn{3}{|c|}{ Molecular spectroscopy } \\
\hline $\begin{array}{l}\text { Absorption of UV/VIS } \\
\text { radiation }\end{array}$ & $\begin{array}{l}\text { UV/VIS molecular absorption spec- } \\
\text { troscopy, spectrophotometry }\end{array}$ & $\begin{array}{l}\text { Qualitative and quantitative determinations of aromatic } \\
\text { and unsaturated organic compounds, including natural } \\
\text { products; direct and indirect quantitative determination of } \\
\text { inorganic ions, organic molecules, and biochemicals }\end{array}$ \\
\hline $\begin{array}{l}\text { Emission of UV/VIS } \\
\text { radiation }\end{array}$ & $\begin{array}{l}\text { Molecular fluorescence, molecular } \\
\text { phosphorescence }\end{array}$ & $\begin{array}{l}\text { Detection of small quantities (<ng) of certain aromatic } \\
\text { compounds and natural products, analysis of gels and } \\
\text { glasses, determination of organic and inorganic species } \\
\text { by "tagging." }\end{array}$ \\
\hline
\end{tabular}

wavelength by molecules (tables 3 and 4). The principle is based on the fact that:

I. Frequency absorbed or emitted by a molecule and the energy of radiation are related by:

$$
\Delta E=h v
$$

II. The amount of energy required depends on the difference in energy (equation 2) between the energy of the ground state $(E 0)$ and the energy of the excited state $(E 1)$ of the electrons.

$$
\Delta E=E 1-E 0=h v
$$

Table 4

WAVELENGTHS = F (RADIATION TYPE) [32]

\begin{tabular}{|c|c|c|c|}
\hline Unit & Symbol & $\begin{array}{c}\text { Length } \\
(\mathbf{m})\end{array}$ & Type of radiation \\
\hline Angstrom & $\AA$ & $10^{-10}$ & X-ray \\
\hline Nanometre & $\mathrm{nm}$ & $10^{-9}$ & $\begin{array}{c}\text { Ultraviolet/ } \\
\text { visible (UV/VIS) }\end{array}$ \\
\hline Micrometre & $\mu \mathrm{m}$ & $10^{-6}$ & Infrared (IR) \\
\hline Millimetre & $\mathrm{mm}$ & $10^{-3}$ & IR \\
\hline Centimetre & $\mathrm{cm}$ & $10^{-2}$ & Microwave \\
\hline Meter & $\mathrm{m}$ & 1 & Radio \\
\hline
\end{tabular}

Quantitative analysis UV/VIS is a sensitive and selective method developed for most elements and many functional groups. It is used extensively in routine analysis of water, food, beverages, industrial products, etc. In general, spectrometers UV/VIS often operates with wavelengths from 800 to $200 \mathrm{~nm}$ (UV radiation has wavelengths from 400 to $200 \mathrm{~nm}$; respective VIS (visible light) have wavelengths from 800 to $400 \mathrm{~nm}$ ). Quantitative measurements by UV/VIS spectrometry are essential in environmental monitoring, industrial process control, including food and beverage manufacturing, pharmaceutical quality control, and chemistry. Quantitative information can also be obtained by studying the absorption or emission of UV and visible radiation by molecules or polyatomic species. The emission of radiation by molecules may occur in several ways (fluorescence and phosphorescence) following the molecule's excitation. In addition, concentrations of solutions can be measured using UV/VIS absorption spectrometry or fluorescence spectrometry.

\section{- X-ray diffraction (XRD)}

Qualitative analysis in the XRD method is used for the measurement of crystal lattice dimensions and to identify the structure and composition of all types of crystalline inorganic and organic materials.

Quantitative analysis in the XRD method is used to determine percent crystallinity in polymers, the composition of mixtures, mixed crystals, soils, and natural products.

\section{- X-ray absorption spectroscopy}

Qualitative analysis in the X-ray absorption reveals the contours and location of high atomic weight elements in the presence of low atomic weight matrixes or holes in the interior of solid samples (voids).

\section{- Gas chromatography (GC)}

Qualitative analysis in the case of the GC method can separate the components of complex mixtures of gases or volatile compounds.

Quantitative analysis in the case of the GC method is an accurate method for quantitative analysis based on the peak area and comparison with standards. Quantitative analysis is used extensively in organic, environmental, clinical, and industrial analysis.

\section{- Thermal analysis (TA)}

Qualitative analysis in the TA method is used to identify inorganic and some organic compounds using small quantities of samples. It is also used to identify phase changes, chemical changes on heating, the heat of fusion, melting points, boiling points, drying 


\begin{tabular}{|l|c|c|c|c|c|c|c|}
\hline \multicolumn{2}{|c|}{ LIST OF SAMPLE TYPES AND PROPERTIES EXAMINED BY THERMAL ANALYSIS METHOD [32] } \\
\hline \multirow{2}{*}{ Properties } & \multicolumn{7}{c|}{ Samples } \\
\cline { 2 - 9 } & Chemicals & Elastomers & Explosives & Soils & Plastics & Textiles & Metals \\
\hline Identification & $\mathrm{x}$ & $\mathrm{x}$ & $\mathrm{x}$ & $\mathrm{x}$ & $\mathrm{x}$ & $\mathrm{x}$ & $\mathrm{x}$ \\
\hline Quantitative composition & $\mathrm{x}$ & $\mathrm{x}$ & $\mathrm{x}$ & $\mathrm{x}$ & $\mathrm{x}$ & $\mathrm{x}$ & \\
\hline Phase diagram & $\mathrm{x}$ & $\mathrm{x}$ & $\mathrm{x}$ & & $\mathrm{x}$ & & $\mathrm{x}$ \\
\hline Thermal stability & $\mathrm{x}$ & $\mathrm{x}$ & $\mathrm{x}$ & & $\mathrm{x}$ & $\mathrm{x}$ & \\
\hline Polymerization & $\mathrm{x}$ & $\mathrm{x}$ & & & $\mathrm{x}$ & $\mathrm{x}$ & \\
\hline Catalytic activity & $\mathrm{x}$ & & & & & & $\mathrm{x}$ \\
\hline Reactivity & $\mathrm{x}$ & $\mathrm{x}$ & & & $\mathrm{x}$ & $\mathrm{x}$ & $\mathrm{x}$ \\
\hline Thermochemical constants & $\mathrm{x}$ & $\mathrm{x}$ & $\mathrm{x}$ & $\mathrm{x}$ & $\mathrm{x}$ & & $\mathrm{x}$ \\
\hline Reaction kinetics & $\mathrm{x}$ & $\mathrm{x}$ & $\mathrm{x}$ & & $\mathrm{x}$ & $\mathrm{x}$ & $\mathrm{x}$ \\
\hline
\end{tabular}

processes, decomposition processes, and compounds' purity (table 5).

Quantitative analysis in the TA method can be used for the quantitative determination of the components of an inorganic sample, particularly at high concentration levels (table 5).

\section{- Differential scanning calorimetry (DSC)}

DSC monitors the difference in temperature between a sample and a reference material as a function of time and temperature in a specified atmosphere.

Quantitatively measures heat absorbed or released by a material undergoing a physical or chemical change. DSC is not temperature-dependent; DSC is used for quantitative measurements of $\Delta H$ and heat capacity. Information obtained Glass transition, melt and phase-change temperatures, heats of reaction, heat capacity, crystallinity, aging, degradation, and thermal history (table 6).

Table 6

\begin{tabular}{|l|c|}
\hline \multicolumn{2}{|c|}{ DSC METHOD APPLICATIONS } \\
\hline \multicolumn{1}{|c|}{ Applications } & DSC method \\
\hline Compositional analysis & $\mathrm{x}$ \\
\hline Curing studies & $\mathrm{x}$ \\
\hline Glass transition & $\mathrm{x}$ \\
\hline Heat of reaction & $\mathrm{x}$ \\
\hline Oxidative stability & $\mathrm{x}$ \\
\hline Corrosion & $\mathrm{x}$ \\
\hline Creep & - \\
\hline Stress relaxation & - \\
\hline Thermal stability & $\mathrm{x}$ \\
\hline Viscoelastic properties & $\mathrm{x}$ \\
\hline Protein denaturation & - \\
\hline Shrinkage & $\mathrm{x}$ \\
\hline
\end{tabular}

\section{TECHNICAL SPECIFICATIONS INTEGRATION AND LABELING}

A technical specification document defines the requirements for a textile material or final product.

\section{Technical specifications integration and testing} role

The testing activity is important to verify the product properties or develop the technical specifications sheet that should provide:

- the minimum requirements for the mechanical, physical and chemical properties of the products that your company purchases or produces;

- ensure that the quality of your products meets your expectations/your customers' expectations;

- prevent miscommunication between the producer, supplier, purchaser and retailer;

- to ensure that the customers are satisfied and you will not receive complaints.

Complications may occur when the product properties are not described in sufficient detail. However, it is impossible to detect the defects (durability, shrink, fade in use) visually when we buy a product.

The textile product should have several performance indicators and should be able to confer:

- Fire safety;

- UV protection;

- Friction resistance;

- Chemicals resistance and to contain allowed chemicals and not prohibited, according to the REACH (Registration, Evaluation, Authorization and Restriction of Chemicals).

In $\mathrm{REACH}[37,38]$ are presented the requirements for chemicals that are allowed or prohibited from use in your products.

Usually, consumers or textile specialists cannot see or feel if textile products contain harmful substances, but chemical analyses can identify the presence of prohibited chemical substances.

The absence of the harmfully chemical can be certified by:

- STANDARD 100, ECO PASSPORT and MADE IN GREEN by OEKO-TEX® [37] certify that your products guarantee that they do not contain any chemical compounds known to be harmful.

- OEKO-TEX* certify that your products comply with the requirements of $\mathrm{REACH}$, the EU law regulating chemicals, and the substances on the SVHC (Substances of Very High Concern) list [38]. 


\section{Safety requirements}

In the EU, the General Product Safety Directive (GPSD) $[40,41]$ regulates all products and the manufacturers and distributors carry the responsibility not to bring products on the market, which present a health or safety hazard towards or property when used in the manner intended. There are many safety issues, such as fire, fall accidents, choking, chemical content, etc. The requirements and the testing methods of the textile products are given in the standards. For example, the requirement for protective clothing is focused on health and ergonomics aspects, design, comfort, cleaning/washing, the size used for pattern design of the protective clothing.

Health and ergonomic requirements for protective clothing (ISO 13688:2013) [42] specify that the protective clothing:

- should not affect the health or hygiene of the user;

- the textile fabrics should not release toxic, carcinogenic, mutagenic, allergenic, toxic to reproduction or otherwise harmful substances;

- materials should be selected to minimize the environmental impact of the production and disposal of protective clothing;

Each layer of material of the protective clothing shall comply with the following requirements:

- all metallic materials which could come into prolonged contact with the skin (e.g. studs, fittings) shall have a release of nickel of less than 0,5 $\mu \mathrm{g} / \mathrm{cm}^{2}$ per week;

- protective clothing material shall have a $\mathrm{pH}$ value in the interval 3.5-9.5;

- Carcinogenic Azo colorants should not be used.

Design requirements consist in:

- using the adequate design of protective clothing that facilitate its correct positioning on the user and shall ensure that it remains in place for the foreseeable period of use, taking into account ambient factors, together with the movements and postures that the wearer could adopt during the course of work or other activity;

- using adequate adjustment systems or adequate size ranges shall be provided to enable protective clothing to be adapted to the morphology of the user.

\section{Comfort requirements}

The protective clothing shall provide users with a level of comfort consistent with the level of protection required against the hazard, the ambient conditions, the level of the user's activity, and the anticipated duration of use of the protective clothing.

- Cleaning/washing requirements

- Size requirements

\section{Product labelling}

Product labelling is necessary for selling part, offering the consumers information about product type, performance parameters and usage conditions.

How can we decide the performance of the product?

- Overall, the consumers and textile specialists cannot see or feel the performance of a textile.
- The manufacturer can evaluate the performance characteristics of a product by testing.

- The purchaser should obtain the documentation of the successful fulfilment of any applicable requirements.

Why it is necessary to specify the requirements on the product label?

- A labelling system can help to inform the consumer of the requirements that the products have fulfilled.

- Specification requirements will inform the consumer of the quality and properties of the product.

Several integrated labelling solutions are available:

- Test the parameters of your products and use a label with a hangtag after successful completion of testing in accredited laboratories.

- A hangtag informs the consumer that the requirements of the product complied with and assures the standard of quality.

- A hangtag with a barcode [43] (figure 3), will enable the consumer to receive informative videos on smartphones about the characteristics of your product.

- Brand protection by use anti-counterfeit features for brand protection based on advanced UV inks and yarn, laser yarn, glow-in-the-dark yarn, micro text prints, and watermarks to ensure the authenticity of your products and reduce the risk of counterfeit.

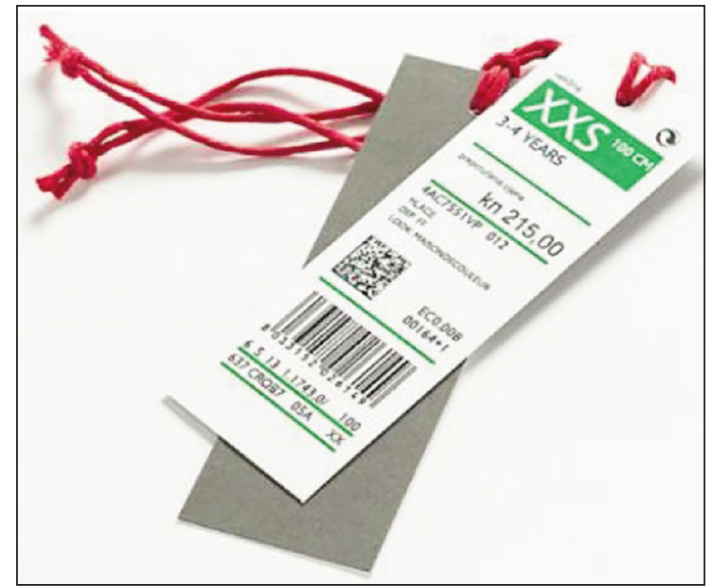

Fig. 3. Barcode hangtag [41]

In addition, the product that has a green label must comply with environmental policy goals (climate change, resource use and sustainable consumption and production) and a better environment according to the GPP (Green Public Procurement) [44-47]. GPP approaches include also restricting hazardous substances in textiles, or requiring operators to demonstrate that timber has been sustainably sourced. EU GPP specifies relevant production methods for some product and service groups, including electricity, textiles and food. Labels and GPP criteria are useful reference points, as they are based on scientific information and life-cycle assessment of the materials and substances found in the covered products and services. Green labels (Eco-labels and Green stickers) are labelling systems for consumer products [46, 47, 
48]. Green label is officially recognized as a method for companies to make:

- transparent environmental declarations;

- claims about their products such as materials used (natural, recycled, eco-friendly), the energy consumption in the manufacturing process.

In the EU, the EU Ecolabel, established in 1992, has the scope to encourage businesses to market products and services that are kinder to the environment [48-50]. EU Ecolabel covers 34 products and services including paper, textiles, cleaning products, lubricants, appliances, home and garden products and tourist accommodation. On many textile products, we can be recognized the OEKO-TEX® label provided by OEKO-TEX® which is an organization that has several members: 18 independent research and test institutes in the field of textile and leather ecology in Europe and Japan with contact offices in more than 60 countries. The partner institutes develop test methods and limit values, which form the basis for the standards (STANDARD 100 by OEKOTEX®, MADE IN GREEN by OEKO-TEX® and LEATHER STANDARD by OEKO-TEX®) for labelling or product certification according to STeP by OEKOTEX® (Sustainable Textile \& Leather Production), ECO PASSPORT by OEKO-TEX® (chemical certification).

\section{CONCLUSIONS}

This paper offers some definitions, examples and practical applications of the international conformity certification, labelling and technical specifications, quality management, environmental legislation and inspection/testing (physico-mechanical testing, colour fastness testing and instrumental analysis). For example, these courses about instrumental analysis succinctly presented by applications, are very usefully for engineers and researchers, specialized in the textiles field, to have a global overview of the tests that can be performed on the textile materials and how to request adequate tests to obtain quickly the information about the textile materials (e.q. presence of the other contaminants on the textile surface or of the micro/nanoparticles). In conclusion, the courses modules developed were successfully delivered and the feedback was very positive from the students and researchers.

\section{ACKNOWLEDGMENTS}

The research presented in this paper was prepared within INCDTP. Funds support this work are from the Erasmus+ programme of the European Union, Project FOSTEX "Fostering innovation in the Jordan and Moroccan textile industry", project no. 598347-EPP-1-2018-1-ES-EPPKA2CBHE-JP.

This project has been funded with support from the European Commission. This publication [communication] reflects the views only of the author, and the Commission cannot be held responsible for any use which may be made of the information contained therein.

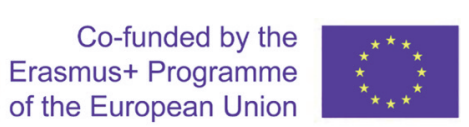

\section{REFERENCES}

[1] Biesta, G., Allan, J., Edwards, R., The theory question in research capacity building in education: Towards an agenda for research and practice, In: British Journal of Educational Studies, 2011, 59, 3, 225-239

[2] Prakash, Y., Charwak, B., Kumar, P.V., Textile industry in new India: challenges and opportunities, In: International Journal of Indian Culture and Business Management, 2020, 21, 4, 435-458

[3] Certification, Available at: https://www.iso.org/certification.html [Accessed on April 2020]

[4] COC - Certificate of Conformance, Available at: www.labhut.com/education-centre/dissolution-accessories/coccertificate-of-conformance-vs-coa-certificate-of-analysis.html [Accessed on April 2020]

[5] The 'Blue Guide' on the implementation of EU products rules 2016, European Commission, 2016/C 272/01

[6] ISO 9001:2015 - Quality management systems - Requirements

[7] ISO 9000:2015 - Quality management systems - Fundamentals and vocabulary

[8] Morris, A.S., Measurement and calibration requirements for quality assurance to ISO 9000, Wiley, 1997

[9] Quality assurance vs. control, Available at: https://asq.org/quality-resources/quality-assurance-vs-control [Accessed on April 2020]

[10] ISO/IEC 17000:2020, Conformity assessment - Vocabulary and general principles

[11] ISO/IEC 17025:2017, General requirements for the competence of testing and calibration laboratories

[12] ISO 13934-1:2013, Textiles - Tensile properties of fabrics. Part 1: Determination of maximum force and elongation at maximum force using the strip method

[13] ISO 13934-2:2014, Textiles - Tensile properties of fabrics. Part 2: Determination of maximum force using the grab method

[14] ISO 13935-1:2014, Textiles - Seam tensile properties of fabrics and made-up textile articles. Part 1: Determination of maximum force to seam rupture using the strip method

[15] ISO 13935-2:2014, Textiles - Seam tensile properties of fabrics and made-up textile articles. Part 2: Determination of maximum force to seam rupture using the grab method

[16] ISO 105-E04:2013, Textiles - Tests for colour fastness. Part E04: Colour fastness to perspiration 
[17] ISO 105-C10:2006, Textiles - Tests for colour fastness. Part C10: Colour fastness to washing with soap or soap and soda

[18] ISO 105-C06:2010, Textiles - Tests for colour fastness. Part C06: Colour fastness to domestic and commercial laundering

[19] ISO 105-B01:2014, Textiles - Tests for colour fastness. Part B01: Colour fastness to light: Daylight

[20] ISO 105-B02:2014, Textiles - Tests for colour fastness. Part B02: Colour fastness to artificial light: Xenon arc fading lamp test

[21] ISO 105-E01:2013, Textiles - Tests for colour fastness. Part E01: Colour fastness to water

[22] ISO 105-D02:2016, Textiles - Tests for colour fastness. Part D02: Colour fastness to rubbing: Organic solvents

[23] ISO 105-X16:2016, Textiles - Tests for colour fastness. Part X16: Colour fastness to rubbing: Small areas

[24] ISO 105-X12:2016, Textiles - Tests for colour fastness. Part X12: Colour fastness to rubbing

[25] ISO 105-X11:1994, Textiles - Tests for colour fastness. Part X11: Colour fastness to hot pressing

[26] Holler, F.J., Skoog, D.A., Crouch, S.R., Chapter 1. Principles of Instrumental Analysis (6th ed.), Cengage Learning, 2007, 9

[27] Skoog, D.A., Hollar, F.J., Crouch, S.R., An Introduction to Ultraviolet-Visible Molecular Absorption Spectrometry. Principles of Instrumental Analysis, 6th ed, Harayana: Thomson, 2007, 336-337

[28] Skoog, D.A., Holler, F.J., Crouch, S.R., Principles of instrumental analysis, Cengage learning, 2017

[29] Lanigan, K.C., Teaching analytical method development in an undergraduate instrumental analysis course, In: Journal of Chemical Education, 2008, 85, 1, 138

[30] Willard, H.H., Merritt Jr, L.L., Dean, J.A., Settle Jr, F.A., Instrumental methods of analysis, 1988

[31] Pungor, E., Horvai, G., A practical guide to instrumental analysis, CRC Press, 1994

[32] Robinson, J.W., Frame, E.S., Frame II, G.M., Undergraduate instrumental analysis, CRC Press, 2014

[33] Rouessac, F., Rouessac, A., Chemical analysis: modern instrumentation methods and techniques, John Wiley \& Sons, 2013

[34] Morris, A.S., Measurement and instrumentation principles, 2001

[35] Morris, A.S., Langari, R., Measurement and instrumentation: theory and application, Academic Press, 2012

[36] Riley, W.F., McConnell, K.G., Dally, J.W., Dally, J., Dally, J., Instrumentation for engineering measurements, Wiley, 1993

[37] Johnson, C.D., Process control instrumentation technology, Pearson, 2014

[38] Perry, D.R., Appleyard, H.M., Cartridge, G., Cobb, P.G.W., Coop, G.E., Lomas, B., Ritchie, G.G., Taylor, C., Welch, M.J., Farnfield, C.A., Identification of textile materials, 1985

[39] REACH, Available at: ec.europa.eu/environment/chemicals/reach/reach_en.htm [Accessed on April 2020]

[40] Understanding REACH, Available at: https://echa.europa.eu/regulations/reach/understanding-reach [Accessed on April 2020]

[41] OEKO-TEX, Available at: www.oeko-tex.com [Accessed on April 2020]

[42] Candidate List of substances of very high concern for Authorisation, Available at: echa.europa.eu/candidate-listtable [Accessed on April 2020]

[43] Directive 2001/95/EC of the European Parliament and of the Council on general product safety, European Commission

[44] ISO 13688:2013, Protective clothing - General requirements

[45] Barcode-Hashtag, Available at: sourcing-media.hktdc.com/product-original/Barcode-Hangtag [Accessed on April 2020]

[46] Green Public Procurement (GPP), Available at: ec.europa.eu/environment/gpp/index_en.htm [Accessed on April 2020]

[47] Report - Textiles Technical Background Report, Green Public Procurement, European Commission, 2011

[48] EU green public procurement criteria for textiles products and services, European Commission

[49] Buying green!, A handbook on green public procurement, 3rd Edition, Contract № 071201/2014/692772// SER/ENV.F.1, European Commission and ICLEI - Local Governments for Sustainability, 2014

[50] Guidance on the implementation/application of directive 2015/29/EC on unfair commercial practices, European Commission

Authors:

RALUCA MARIA AILENI, LAURA CHIRIAC, RAZVAN ION RADULESCU

National Research Development Institute for Textiles and Leather,

16 Lucretiu Patrascanu Street, 030508, Bucharest, Romania

Corresponding author:

RALUCA MARIA AILENI

e-mail: raluca.aileni@incdtp.ro 